\title{
A fresh look at shifting cultivation: Fallow length an uncertain indicator of productivity
}

\author{
Ole Mertz $^{\mathrm{a}, *}$, Reed L. Wadley ${ }^{\mathrm{b}}$, Uffe Nielsen ${ }^{\mathrm{c}, 1}$, Thilde B. Bruun ${ }^{\mathrm{a}}$, Carol J.P. Colfer ${ }^{\mathrm{d}}$, \\ Andreas de Neergaard ${ }^{\mathrm{e}}$, Martin R. Jepsen ${ }^{\mathrm{a}}$, Torben Martinussen ${ }^{\mathrm{f}}$, Qiang Zhao ${ }^{\mathrm{g}}$, \\ Gabriel T. Noweg ${ }^{\mathrm{h}}$, Jakob Magid ${ }^{\mathrm{e}}$ \\ ${ }^{a}$ Department of Geography and Geology, University of Copenhagen, Øster Voldgade 10, 1350 Copenhagen K, Denmark \\ ${ }^{\mathrm{b}}$ Department of Anthropology, University of Missouri-Columbia, 107 Swallow Hall, Columbia, MO 65211, USA \\ ${ }^{c}$ Department of Food and Resource Economics, University of Copenhagen, Rolighedsvej 25, 1958 Frederiksberg C, Denmark \\ ${ }^{\mathrm{d}}$ Center for International Forestry Research (CIFOR), P.O. Box 6596, JKPWB, Jakarta 10065, Indonesia \\ e Department of Agricultural Sciences, University of Copenhagen, Thovaldsensvej 40, 1871 Frederiksberg C, Denmark \\ ${ }^{\mathrm{f}}$ Department of Natural Sciences, University of Copenhagen, Thovaldsensvej 40, 1871 Frederiksberg C, Denmark \\ ${ }^{\mathrm{g}}$ Department of Mathematics, Texas State University, 601 University Drive, San Marcos, TX 78666, USA \\ ${ }^{\text {h }}$ Centre for Applied Learning, Universiti Malaysia Sarawak, 94300 Kota Samarahan, Sarawak, Malaysia
}

Received 7 November 2006; received in revised form 8 June 2007; accepted 12 June 2007

Available online 30 July 2007

\begin{abstract}
Shifting cultivation is practiced by millions of farmers in the tropics and has been accused of causing deforestation and keeping farmers in poverty. The assumed positive relationship between fallow length and crop yields has long shaped such negative opinions on the sustainability and environmental impact of the system, as population growth is believed inevitably to lead to its collapse. Empirical evidence for this assumption is scarce, however, and a better understanding of system dynamics is needed before discarding shifting cultivation as unsustainable. With cases from Malaysia and Indonesia, we show that fallow length is a weak predictor of crop yields, though interactions with fertilizer inputs may increase its importance. Other factors such as drought, flooding, and pests are more important determinants of yields. The implication is that when using natural fallow as the only means of nutrient supply, there is no need to cut old fallow vegetation. Moreover, there is no evidence of system collapse, even at short fallow periods. We conclude that shifting cultivation should be accepted as a rational land use system and that earlier calls for bringing a "Green Revolution" to shifting cultivators are still relevant to achieve intensive and sustainable production.
\end{abstract}

(c) 2007 Elsevier Ltd. All rights reserved.

Keywords: Borneo; Fallow; Kalimantan; Land use; Rice production; Sarawak; Southeast Asia; Upland rice

\section{Introduction}

Despite rapid economic development in many tropical countries, millions of people, particularly in the humid tropics, still practice some form of shifting cultivation

\footnotetext{
* Corresponding author. Tel.: +45 3532 2529; fax: +453532 2501.

E-mail address: om@geogr.ku.dk (O. Mertz).

${ }^{1}$ Present address: Danish Economic Council, Amaliegade 44, 1256 Copenhagen K, Denmark.
}

(swidden or slash-and-burn agriculture). Exact figures on the areas under shifting cultivation worldwide do not exist, but there is an estimated 850 million ha of secondary forest in tropical Africa, America and Asia (FAO, 2005) of which shifting cultivators occupy an important part. Figures for the number of people depending on this system are also uncertain and range from 40 to 500 million (Russell, 1988; Goldammer, 1988; Kleinman et al., 1996; Sanchez et al., 2005). There is no doubt that despite rapid change and conversion to other land uses (Padoch et al., 2007), 